\title{
PENGARUH PARTISIPASI EKSEKUTIF DAN KOMPLEKSITAS SISTEM TERHADAP SISTEM INFORMASI PADA PERUSAHAAN KONSTRUKSI DI KOTA MATARAM
}

\author{
Baiq Adriani Ulfa \\ Akuntansi Universitas Bumigora \\ baiqadrianiulfa@universitasbumigora.ac.id
}

\begin{abstract}
The title of this research is "The Excecutives Participation and System Complexity Concerning The Development of Information System at the construction Company in Mataram City" which is intended for knowing the simultaneously and partially influence between excecutive's participation and system complexity concerning the development of information system.

The sample determined which is used in this research is the stratified random sampling method with 56 people samples. The hypothetic test which used is the double linier regression. The F test is used for knowingthe influence of independent variable concerning the dependent variable concerning the dependent variable partially.

Based on the analysis which have done before, known that the excecutive's participation and system complexity variable is influenced simultaneously concerning the development of information system. The result of second hypothetic analysis showed that the eexecutive's participation had influenced partially concerning the development of information system, while system complexity had it.

Based on the research result that have gotten, the next researcheris hoped to develop more sample or to add the other variable which is predicted that it has influence ininformation system development, like the communication of user developerand user affect and take a sample industry building on process (continues product).
\end{abstract}

Keywords: Executive Participation, System Complexity, Information System.

\section{PENDAHULUAN}

Pembangunan ekonomi Indonesia dewasa ini dihadapkan pada kemajuan yang pesat. Hal ini dapat dilihat dari tingkat persaingan bisnis antar perusahaan, baik yang dikelola langsung oleh negara maupun perusahaan yang dimiliki oleh pihak swasta. Sejalan dengan kondisi ini, setiap perusahaan dihadapkan pada suatu sistem yang tepat untuk menarik minat konsumennya guna menguasai pangsa pasarnya. Berbagai macam sistem yang diterapkan dalam setiap perusahaan sehingga dapat menghasilkan suatu keputusan yang tepat dan sesuai dengan kondisi saat ini.

Salah satu yang menjadi landasan suatu keputusan setiap perusahaan adalah bagaimana ketepatan dalam pemakaian sistem informasi. Sistem informasi yang jelas dan lengkap, baik itu secara internal maupun eksternal sangat membantu manajer sebagai eksekutif dalam pengambilan keputusannya untuk mencapai tujuan perusahaan (Jogiyanto, 2005:54).

Perkembangan sistem informasi pada setiap perusahaan di Indonesia sangat memegang peranan penting. Pengembangan sistem informasi tersebut tidak terlepas dari kelengkapan teknologi informasi yang menjadi awal dari kelengkapan sistem. teknologi informasi yang dimaksud juga dapat memberikan motivasi kerja dari setiap individu pada perusahaan untuk melakukan tugas fungsionalnya.

Pada kenyataannya, pengembangan sistem informasi memerlukan perencanaan dan implementasi yang hati-hati untuk menghindari adanya penolakan terhadap sistem yang dikembangkan (resistenci to 
change). Untuk menghindari adanya penolakan terhadap sistem yang dikembangkan (resistenci to change), maka diperlukan adanya partisipasi dari pemakai (Ginzberg, 1981:Szjana dan Scammel et al., 1993; Hurton dan Kenneth et al., 1994; Choe, 1996) dalam Lau (2003:866).

Kelengkapan sistem informasi juga akan menunjang para eksekutif atau dengan kata lain manajemen puncak dalam pengambilan kebijakan perusahaan, sehingga dalam prosesnya alur dari kebijakan tersebut dapat diterima oleh semua pihak dengan dukungan yang erat dari teknologi informasi tersebut.

Partisipasi dapat dikatakan dengan turut mengambil bagian. Seseorang dikatakan berpartisipasi jika telah memberikan suatu kontribusi. Juga bertanggung jawab terhadap kesejahteraan perusahaan.

Pengembangan sistem informasi, partisipasi eksekutif akan membawa pengaruh yang baik terhadap organisasi, tentunya berkomunikasi dengan para pemakai, oleh karena itu perlu mengidentifikasi kebutuhan sistem. Partisipasi eksekutif memiliki pengaruh untuk mensosialisasikan pengembangan sistem informasi, yang memungkinkan pemakai untuk berpartisipasi dalam setiap tahap pengembangan sistem informasi dan ini akan berpengaruh pada kepuasan pemakai.

Pengembangan sistem informasi dengan teknologi komputer juga akan meliputi perubahan pada bagian-bagian komputer untuk dimodifikasi menjadi lebih canggih, sehingga dapat memberikan informasi yang cepat, tepat dan akurat. Bagian-bagian komputer yang sering dikembangkan meliputi bagian software (perangkat lunak) dan hardware (perangkat keras) (Husein dan Wibowo, 2002:12).

Berdasarkan uraian di atas, sistem informasi yang dipandu dengan kelengkapan teknologi informasi yang berbasis komputer sangatlah penting, sehingga akan tercapai kelengkapan sistem yang dikenal dengan kompleksitas sistem. Sebesar apapun perusahaan tanpa adanya kompleksitas sistem, dapat dipastikan perusahaan tersebut akan mengalami kemunduran. Kompleksitas sistem yang dimaksud dalam penelitian ini mengacu pada teknologi yang digunakan oleh suatu organisasi dengan anggapan bahwa kompleksitas adalah relatif terhadap setiap organisasi dan tidak mutlak (Lau, 2003:872). Sistem yang kompleks ini tidak terlepas dari partisipasi eksekutif secara langsung.

Dewasa ini, perusahaan konstruksi di kota Mataram mulai berkompetisi untuk menguatkan kompleksitas sistemnya dalam menguasai pangsa pasar. Pengembangan kompleksitas sistem tersebut tidak lain harus didukung dengan sistem teknologi modern.

Perusahaan konstruksi adalah perusahaan jasa yang menjadi partner pemerintah dalam menunjang kegiatan pembangunan. Pembangunan yang semakin pesat menyebabkan semakin banyak pula usaha yang bergerak pada bidang konstruksi. Dalam aktivitasnya perusahaan ini sangat membutuhkan informasi yang akurat, relevan, dan tepat waktu. Informasi yang dibutuhkan tidak hanya untuk pengambilan keputusan, tetapi juga untuk melakukan perencanaan dan pengendalian.

\section{KERANGKA KONSEPTUAL DAN HIPOTESIS}

Manajemen puncak atau yang biasa disebut dengan eksekutif memiliki pengaruh untuk mensosialisasikan pengembangan sistem informasi yang berpengaruh pada kepuasan pemakai. Adanya partisipasi eksekutif merupakan salah satu faktor dalam investasi teknologi informasi dan berpengaruh pada kesuksesan pengembangan sistem informasi. Pengembangan sistem dilaksanakan untuk menjamin keefektifannya, terlebih lagi apabila sistem informasi tersebut telah berjalan maka manajemen, pemakai, dan personil sistem diperlukan dalam pengembangan sistem. Dalam pengembangan sistem perlu untuk mengidentifikasi kebutuhan pemakai sistem dan implementasi sistem baru. Selain itu, untuk menunjang kesuksesan suatu persahaan dalam bersaing dan tetap exist diperlukan sistem yang kompleks atau disebut dengan kompleksitas sistem. Sistem yang kompleks dapat membantu eksekutif untuk memperoleh informasi yang akurat, tepat waktu dan relevan yang mampu membantu eksekutif dalam mengambil suatu keputusan demi kepentingan perusahaan. 
Berdasarkan pada uraian di atas, dibuat kerangka konseptual sebagai berikut:

\section{Gambar 1. Kerangka Pengaruh Partisipasi Eksekutif dan Kompleksitas Sistem terhadap Pengembangan Sistem Informasi}

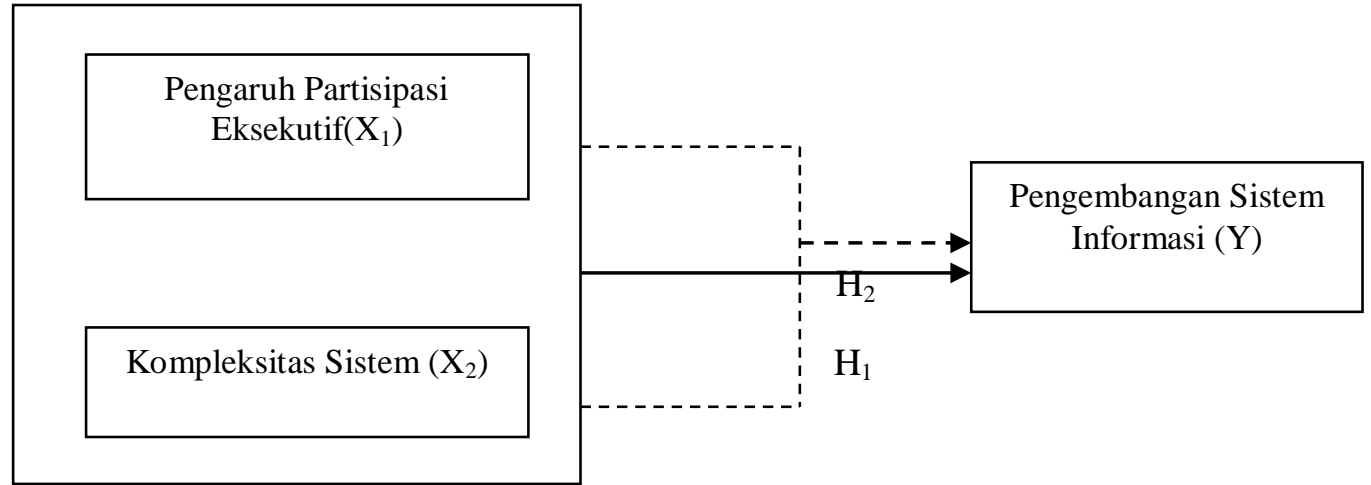

Keterangan:

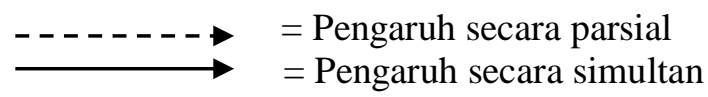

\section{METODE PENELITIAN}

\section{Populasi dan Sampel}

Populasi dalam penelitian ini adalah perusahaan konstruksi yang berlokasi di kota Mataram. Berdasarkan data yang diperoleh terdapat 157 perusahaan konstruksi di Kota Mataram yang terdaftar di Gabungan Pengusaha Indonesia (GAPENSI) Nusa Tenggara Barat.

Sampel adalah sebagian dari elemen-elemen populasi (Indriantoro, dkk 2002:115). Teknik pengambilan sampel yang digunakan dalam penelitian ini adalah Stratified Random Sampling. Teknik Stratified Random Sampling merupakan populasi yang dibagi-bagi menjadi beberapa bagian/ subpopulasi/ stratum (Pangestu Subagyo dan Djarwanto 2005:101). Menurut Arikunto (2006:134) menyatakan apabila subyeknya kurang dari 100, diambil semua sekaligus sehingga penelitiannya penelitian populasi. Jumlah subyek yang dipilih ditentukan dengan menggunakan teknik proportionate random sampling, jika perbedaan jumlah elemen antara strata satu dengan strata lain cukup besar, ada kemungkinan jumlah subyek pada strata tertentu terlalu kecil dan pada strata yang lainnya terlalu besar.

Tabel 1. Distribusi Sampel

\begin{tabular}{|c|c|c|c|}
\hline No. & Grade (Kelas) & Jumlah & $\begin{array}{c}\text { Proporsional (35\% dari } \\
\text { jumlah populasi) }\end{array}$ \\
\hline 1. & 1 & 8 & 3 \\
\hline 2. & 2 & 31 & 11 \\
\hline 3. & 3 & 35 & 12 \\
\hline 4. & 4 & 53 & 19 \\
\hline 5. & 5 & 16 & 6 \\
\hline 6. & 6 & 12 & 4 \\
\hline 7. & 7 & 2 & 56 \\
\hline
\end{tabular}


Dalam penelitian ini, peneliti menggunakan persentase sebesar $35 \%$ dimana hasil total sampel sebesar 56. Peneliti menggunakan persentase sebesar 35\% untuk agar sampel untuk masing-masing grade merata dan untuk memenuhi asumsi kenormalan.

\section{Penentuan Responden}

Responden yang dimaksud dalam penelitian ini adalah manajemen puncak perusahaan konstruksi di Kota Mataram.

\section{Teknik dan Alat Pengumpulan Data}

Teknik pengumpulan data yang dilakukan melalui kuesioner, yaitu dengan membuat pertanyaan dalam bentuk kuesioner yang akan digunakan untuk memperoleh data secara kuantitatif. Kuesioner tersebut akan dibagikan kepada pihak masing-masing eksekutif pada perusahaan konstruksi di Kota Mataram.

\section{Jenis dan Sumber Data}

Jenis data yang digunakan dalam penelitian ini, yaitu kualitatif. Data kualitatif dalam penelitian ini adalah pernyataan responden dalam menjawab kuesioner.

Sumber data yang digunakan dalam penelitian ini adalah data primer. Data primer dalam penelitian ini adalah data diperoleh melalui kuesioner yang dibagikan kepada responden, yaitu manajemen puncak perusahaan konstruksi di Kota Mataram.

\section{Klasifikasi Variabel}

1. Variabel bebas (independen variabel) adalah variabel yang besar kecilnya mempengaruhi besar kecilnya variabel terpengaruh. Variabel tersebut adalah Partisipasi eksekutif dan Kompleksitas sistem.

2. Variabel terpengaruh/ variabel terikat (dependen variabel) adalah variabel yang besar kecilnya ditentukan oleh variabel terpengaruh. Variabel tersebut adalah Pengembangan Sistem Informasi.

\section{Prosedur Analisis Data}

\section{Uji Validitas}

Item yang mempunyai korelasi positif dengan kriterium (skor total) serta korelasi yang tinggi, menunjukkan bahwa item tersebut mempunyai validitas yang tinggi pula. Biasanya syarat minimum untuk dianggap memenuhi syarat adalah kalau $r \geq 0,3$ (Sugiyono, 2002:124).

\section{Uji Realibilitas}

Uji realibilitas dalam penelitian ini dilakukan dengan cara oneshot atau pengukuran sekali saja dan diuji dengan statistic Cronbach alpha ( $\alpha$ ), dengan kriteria variabel dikatakan reliable jika memberikan nilai Cronbach alpha > 0,60 (Nunnnaly, 1967) dalam Ghozali (2006:42).

\section{Uji Asumsi Klasik}

Sebelum data dianalisis lebih lanjut menggunakan analisis regresi berganda, terlebih dahulu akan diuji normalitas, uji heteroskedastisitas dan uji multikolinieritas.

\section{Analisis Regresi Linier Berganda}

Model ini digunakan untuk mengetahui besarnya pengaruh $\mathrm{X}_{1}=$ partisipasi eksekutif, $\mathrm{X}_{2}$ kompleksitas sistem terhadap pengembangan sistem informasi (Y).

Adapun persamaan regresi dalam penelitian ini adalah:

$$
\mathrm{Y}=\beta_{0}+\beta_{1} \mathrm{X}_{1}+\beta_{2} \mathrm{X}_{2}+\mathrm{e}
$$


Keterangan:

$\mathrm{Y} \quad=$ Pengembangan sistem informasi

$\beta_{0} \quad=$ Konstanta

$\beta_{1} \quad=$ Koefisien regresi

$\mathrm{X}_{1} \quad=$ Partisipasi eksekutif

$\mathrm{X}_{2} \quad=$ Kompleksitas sistem

e $\quad=$ Faktor lain

\section{Uji parsial (Uji t)}

Untuk menghitung besarnya pegaruh variabel independen secara parsial digunakan alat analisis statistik uji t.

\section{Uji Simultan atau serentak (F)}

Uji F digunakan unuk mengetahui pengaruh simultan antara partisipasi eksekutif dan kompleksitas sistem terhadap pengembangan sistem informasi.

\section{HASIL DAN PEMBAHASAN}

Dari hasil pengambilan sampel, diperoleh 56 responden dari 56 perusahaan konstruksi di Kota Mataram. Total kuesioner yang disebarkan sejumlah 56 kuesioner. Dari jumlah tersebut, kuesioner yang kembali sebanyak 51 kuesioner.

\section{Deskripsi Responden}

Data kuesioner yang diperoleh sebanyak 51 kuesioner dengan tingkat pengembalian kuesioner sebesar 91\% dari 56 kuesioner yang dikirim. Berikut deskripsi responden yang digunakan dalam penelitian ini.

a. Umur

Umur responden dalam penelitian ini dibagi menjadi 3 kelompok, yaitu 25-30 tahun, 31-35 tahun, dan $>36$ tahun.

b. Jenis Kelamin

Jenis kelamin para eksekutif yang menjadi responden dalam penelitian ini terdiri dari 37 orang pria dan 14 orang wanita.

c. Tingkat Pendidikan

Jenjang pendidikan responden dibagi menjadi 4 kelompok, yaitu Pasca Sarjana (S2), Sarjana strata (S1), Sarjana muda/ Diploma/ yang sederajat, dan Sekolah Menengah Atas/ yang sederajat. Responden yang menjawab kuesioner lebih banyak pada jenjang pendidikan terakhir Sarjana strata satu (S1), sedangkan jenjang pendidikan Pasca Sarjana (S2) tidak ada yang mengisi kuesioner.

\section{Analisis Data}

\section{Distribusi Jawaban Responden}

\section{a. Variabel Partisipasi Eksekutif}

Dari jawaban responden sebagian besar responden mendukung partisipasi eksekutif setelah menggunakan sistem informasi perusahaan mengalami kemajuan dan dapat menghasilkan inovasi, peran sistem informasi yang digunakan selama ini dapat berjalan dengan baik di perusahaan. Hal ini ditunjukkan dengan jawaban setuju dan sangat setuju. Disamping itu, dengan penggunaan sistem informasi perusahaan dapat memberikan peluang untuk mendapatkan proyek. Hal ini ditunjukkan dengan jawaban setuju dan sangat setuju. 


\section{b. Variabel Kompleksitas Sistem}

Dari jawaban responden sebagian besar responden mendukung kompleksitas sistem informasi. Hal ini ditunjukkan dengan jawaban setuju dan sangat setuju responden dalam sistem yang digunakan mampu memberikan dan menyediakan informasi yang akurat, relevan dan tepat waktu. Hal ini ditunjukkan dengan jawaban setuju dan sangat setuju responden. Disamping itu, sistem yang digunakan mampu dimengerti oleh semua pemakai pada masing-masing tingkatan manajemen, teknologi yang digunakan pada perusahaan dapat menunjang kelengkapan sistem sesuai dengan perkembangan saat ini. Hal ini ditunjukkan dengan jawaban setuju dan sangat setuju responden.

\section{c. Variabel Pengembangan Sistem Informasi}

Dari jawaban responden sebagian besar responden mendukung pengembangan sistem informasi. Hal ini ditunjukkan dengan jawaban setuju dan sangat setuju responden bahwa sistem informasi yang ada saat ini pada perusahaan sudah sesuai dengan tuntutan informasi yang dibutuhkan, sistem informasi yang sesuai dengan kemajuan teknologi. Hal ini ditunjukkan dengan jawaban setuju dan sangat setuju responden.

\section{Uji Validitas dan Realibilitas Instrumen Penelitian}

Untuk uji validitas digunakan metode statistic product moment pearson, sedangkan alat uji realibilitas digunakan koefisien realibilitas (cronbach alpha). Pengujian validitas dan realibilitas kuesioner dilakukan dengan program SPSS (Statical Package For Social Science).

\section{Uji Validitas}

Hasil pengujian validitas untuk kuesioner penelitian secara keseluruhan adalah valid. Hal ini ditunjukkan oleh nilai $r_{\text {hitung }}$ dari keseluruhan item lebih besar daripada $r_{\text {kritis }}\left(r_{\text {hitung }} \geq 0,3\right)$. Ketentuan validitas instrumen penelitian ini telah memenuhi syarat dikatakan valid, yaitu jika $r_{\text {hitung }} \geq r_{\text {kritis }}$, sehingga dapat digunakan untuk analisis tahap selanjutnya.

\section{Uji Reliabilitas}

Hasil uji validitas kuesioner penelitian dapat dirangkum ke dalam tabel berikut:

Tabel 2. Ringkasan Hasil Uji Realibiltas

\begin{tabular}{|c|c|c|}
\hline Item & Cronbach Alpha & Keterangan \\
\hline X1 & 0,821 & Reliabel \\
\hline X2 & 0,827 & Reliabel \\
\hline Y & 0,862 & Reliabel \\
\hline
\end{tabular}

Dari tabel di atas, menunjukkan nilai Alpha seluruhnya adalah reliabel karena memilii alpha di atas 0,6 sehingga seluruh variabel yang diteliti adalah reliabel dan dapat digunakan untuk tahap selanjutnya

\section{Uji Asumsi Klasik}

Penelitian ini juga menguji asumsi klasik yang melekat pada persamaan model regresi, sehingga data-data yang digunakan dalam pengujian hipotesis bebas dari asumsi klasik (Ghozali, 2002). Uji asumsi klasik dalam penelitian ini adalah:

\section{a. Uji Normalitas}


Dari tabel One-Sample Kolmogorov-Smirnov Test (Tabel), diperoleh nilai kolmogrov-smirnov adalah $(0,784)$ dan signifikasi $(0,570)$, berarti kita tidak dapat menolak Ho yang mengatakan bahwa residual terdistribusi secara normal atau dengan kata lain data residual terdistribusi secara normal.

\section{a. Uji Heteroskedesitas}

Di dalam penelitian ini untuk menguji ada tidaknya heterokedesitas menggunakan uji gleyser yaitu untuk meregres nilai absolute residual terhadap variabel bebas, jika variabel bebas signifikan secara statistik mempengaruhi variabel terikat, maka ada indikasi terjadi heteroskedasitas antara nilai prediksi variabel terikat dengan residualnya. Adapun hasilnya, dapat dilihat pada tabel di bawah ini.

Tabel 3. Hasil Pengujian Heterokedesitas

\begin{tabular}{|l|c|}
\hline \multicolumn{1}{|c|}{ VARIABEL INDEPENDEN } & SIG. \\
\hline Partisipasi Eksekutif & 0,965 \\
\hline Kompleksitas Sistem & 0,278 \\
\hline
\end{tabular}

Dari tampilan output SPSS diatas dengan jelas menunjukkan tidak ada satupun variabel independen yang signifikan secara statistik mempengaruhi variabel dependen Absolut Ut (ABSUT). Hal ini dilihat dari probabilitas signifikansinya diatas tingkat kepercayaan $5 \%$, jadi dapat disimpulkan bahwa model regresi tidak mengandung adanya heterokedesitas.

\section{b. Uji Multikoleniaritas}

Untuk mengetahui persamaan regresi bebas dari gejala multikolenearitas adalah dengan melihat nilai tolerance $<0,1$ atau dengan melihat Variance Inflation Factor (VIF) mempunyai nilai $>10$.

Tabel 4. Hasil Pengujian Multikoleniaritas

\begin{tabular}{|l|c|c|}
\hline \multicolumn{1}{|c|}{ VARIABEL INDEPENDEN } & T & VIF \\
\hline Partisipasi Eksekutif & 0,891 & 1,122 \\
\hline Kompleksitas Sistem & 0,891 & 1,122 \\
\hline
\end{tabular}

Berdasarkan analisa diatas dapat disimpulkan bahwa model regresi ini tidak terjadi gejala multikolinearitas, karena tidak satupun yang memiliki nilai VIF lebih dari 10, dan tidak ada yang memiliki nilai Tolerance kurang dari $(0,1)$.

\section{Analisis Regresi}

Untuk dapat mengetahui pengaruh variabel-variabel independen terhadap variabel dependen maka digunakanlah analisis regresi dengan bantuan perangkat program SPSS yang secara rinci disajikan pada lampiran. Adapun variabel independen yang dimaksud adalah Partisipasi Eksekutf ( $\left.\mathrm{X}_{1}\right)$, Kompleksitas Sistem $\left(\mathrm{X}_{2}\right)$, dan Pengembangan Sistem Informasi (Y) sebagai variabel dependen.

Dari hasil pengolahan data diketahui bahwa nilai regresi sebesar 0,424 yang berarti nilai regresi ini menunjukkan secara statistik ada hubungan variabel partisipasi eksekutif dan kompleksitas sistem sebagai variabel independen dengan pengembangan sistem informasi sebagai variabel dependen. Dari perhitungan juga diketahui nilai koefisien determinasi $\left(\mathrm{R}^{2}\right)$ sebesar 0,180 yang berarti bahwa secara statistik variabel-variabel bebas (partisispasi eksekutif dan kompleksitas sistem) mampu menjelaskan variasi dari variabel pengembangan sistem informasi sebesar $18 \%$ dan sisanya $82 \%$ dijelaskan oleh faktor lain di luar variabel-variabel bebas yang dianalisis. 
Berdasarkan hasil analisis regresi pada lampiran 3, diperoleh model sebagai berikut:

$$
Y=27,756+0,266 X_{1}+0,272 X_{2}+e
$$

\section{Pengujian Hipotesis}

\section{Pengujian Secara Parsial (uji t)}

Adapun proses pengujiannya adalah sebagai berikut:

a. Rumusan Hipotesa

Ho : $\beta=0$, artinya tidak terdapat pengaruh yang signifikan secara parsial antara partisipasi eksekutif dan kompleksitas sistem terhadap pengembangan sistem informasi.

Ha $: \beta \neq 0$, artinya terdapat pengaruh pengaruh yang signifikan secara parsial antara partisipasi eksekutif dan kompleksitas sistem terhadap pengembangan sistem informasi.

b. Menentukan level of significant $(\alpha)=5 \%$ untuk menentukan $t_{\text {tabel }}$, namun karena dilakukan uji 2 arah, sehingga diperoleh $t_{\text {tabel }}$ sebesar 1,676

Sumber: Lampiran 6

c. Membandingkan $t_{\text {hitung }}$ dengan $t_{\text {tabel }}$

Kriteria pengujian:

Ho diterima apabila $-\mathrm{t}_{\text {hitung }} \geq \mathrm{t} \alpha \leq \mathrm{t}_{\text {tabel }}$

Ha ditolak apabila $t_{\text {hitung }}>\mathrm{t} \alpha$ atau $-\mathrm{t}_{\text {hitung }}<\mathrm{t} \alpha$

Tabel 17. Kriteria Signifikansi antara Partisipasi Eksekutif dan Kompleksitas Sistem dalam pengembangan Sistem Informasi

\begin{tabular}{|l|c|c|c|c|}
\hline No. & Variabel & $\mathbf{t}_{\text {hitung }}$ & $\begin{array}{c}\mathbf{t} \boldsymbol{\alpha} \% \text { (two } \\
\text { tail test) }\end{array}$ & Kriteria \\
\hline 1. & Partisipasi Eksekutif & 1,986 & 1,676 & Ho diterima \\
\hline 2. & Kompleksitas Sistem & 1,764 & 1,676 & Ho diterima \\
\hline
\end{tabular}

d. Kesimpulan

Berdasarkan tabel di atas, diketahui bahwa variabel partisipasi eksekutif mempunyai pengaruh yang signifikan terhadap pengembangan sistem informasi, karena nilai $\mathrm{t}_{\text {hitung }}$ untuk variabel partisipasi eksekutif lebih besar dari $t_{\text {tabel }}(1,986 \leq 1,676)$. Dan $t_{\text {hitung }}$ partisipasi eksekutif sebesar 1,986 sedangkan kompleksitas sistem sebesar 1,764. Kompleksitas sistem mempunyai pengaruh yang signifikan terhadap pengembangan sistem informasi.

\section{Uji Simultan (F)}

Adapun langkah-langkahnya sebagai berikut:

a. Rumusan Hipotesa

Ho : $\beta=0$, artinya tidak terdapat pengaruh yang signifikan secara simultan antara partisipasi eksekutif dan kompleksitas sistem terhadap pengembangan sistem informasi.

Ha $: \beta \neq 0$, artinya terdapat pengaruh pengaruh yang signifikan secara simultan antara partisipasi eksekutif dan kompleksitas sistem terhadap pengembangan sistem informasi.

b. Penentuan Statistik tabel dengan nilai $\alpha$ (tingkat kesalahan yang dapat ditolerir) dalam penelitian ini adalah sebesar 5\%, dan $\mathrm{df}=\mathrm{n}-\mathrm{k}-1=51-1=50$. Sehingga diperoleh $\mathrm{F}_{\text {tabel }}$ sebesar 4,03

c. Menentukan besarnya $F_{\text {hitung }}$

Besarnya $F_{\text {hitung }}$ yang diperoleh dari hasil pengujian dengan menggunakan SPSS versi 16.0 yaitu sebesar 5,257

d. Membandingkan $F_{\text {hitung }}$ dengan $\mathrm{F}_{\text {tabel }}$

Kriteria pengujian:

Ho diterima apabila $\mathrm{F}_{\text {hitung }} \leq \mathrm{F}_{\text {tabel }}$

Ho ditolak apabila $\mathrm{F}_{\text {hitung }}>\mathrm{F}_{\text {tabel }}$ 
Dari kriteria pengujian tersebut dapat terlihat bahwa $F_{\text {hitung }}(5,257)>F_{\text {tabel }}(4,03)$, maka Ho ditolak dan Ha diterima.

e. Kesimpulan

Pada kriteria pengujian di atas, dapat dilihat bahwa nilai $\mathrm{F}_{\text {hitung }}$ lebih besar dari $\mathrm{F}_{\text {tabel }}(5,257>$ 4,03), Hasil regresi pada lampiran 6 menunjukkan angka yang signifikan secara bersama-sama (simultan) antara partisipasi eksekutif dan kompleksitas sistem terhadap pengembangan sistem informasi diperoleh $\mathrm{F}$ hitung sebesar 5,257 dengan probabilitas 0,009 berarti angka ini jauh dibawah angka 0,05 .

\section{Interpretasi Hasil}

Dari penelitian yang telah dilakukan, diperoleh hasil bahwa partisipasi eksekutif pengaruh yang signifikan terhadap pengembangan sistem informasi. Pengaruh yang ditimbulkan adalah positif, yaitu semakin tinggi tingkat partisipasi eksekutif maka semakin baik pengembangan sistem informasi yang dihasilkan. Hal ini dapat menunjukkan bahwa dukungan manajemen puncak merupakan faktor penting dan berpengaruh pada kesuksesan pengembangan sistem informasi perusahaan dan lebih khusus lagi pada perencanaan sistem informasi. Partisipasi manajemen puncak/ eksekutif dikonsentrasikan pada perilaku eksekutuif yang berhubungan dengan perencanaan sistem informasi, pengembangan dan implementasinya. Sedangkan keterlibatan manajemen puncak/ eksekutif menggambarkan persepsi dan sikap yang berhubungan dengan pengembangan sistem informasi. Hasil penelitian ini sejalan dengan penelitian yang dilakukan oleh Lau (2003).

Variabel kompleksitas sistem mempunyai pengaruh yang signifikan terhadap pengembangan sistem informasi. Pengaruh yang ditimbulkan adalah positif, yaitu semakin tinggi tingkat kompleksitas sistem maka pengembangan sistem informasi yang dihasilkan semakin baik. Kompleksitas sistem yang mengacu pada teknologi yang digunakan dalam organisasi/ perusahaan. Hal ini dapat menunjukkan bahwa kompleksitas sistem dapat membantu dan mempermudah dalam menyelesaikan pekerjaan/ aktivitas dan menyebabkan terjadinya berbagai perubahan seperti pencatatan tenaga kerja diganti dengan sistem data base, mesin hitung diganti dengan excel dan perubahan-perubahan lainnya. Hasil penelitian ini sejalan dengan penelitian yang dilakukan oleh Lau (2003). Variabel partisipasi eksekutif $\left(X_{1}\right)$ dan kompleksitas sistem $\left(\mathrm{X}_{2}\right)$ secara bersama-sama (simultan) mempunyai pengaruh yang signifikan terhadap pengembangan sistem informasi.

Hal ini sesuai dengen penelitian Puspawati (2007). Besarnya pengaruh kedua variabel tersebut terhadap pengembangan sistem informasi. Besarnya pengaruh kedua variabel tersebut terhadap pengembangan sistem informasi adalah sebesar $18 \%$ menurut Sugiyono (2002:183) pengaruh tersebut termasuk dalam kategori sangat rendah, sedangkan sebesar $82 \%$ termasuk dalam kategori sangat kuat dipengaruhi oleh faktor lain (Lampiran 5). Faktor lain yang mempengaruhi pengembangan sistem informasi selain kedua variabel tersebut, antara lain komunikasi pemakai pengembang dan pengaruh pemakai.

\section{KESIMPULAN}

Berdasarkan hasil analisis dan pembahasan pada bab sebelumnya diperoleh kesimpulan:

1. Secara simultan variabel partisipasi eksekutif dan kompleksitas sistem bahwa secara bersama-sama (simultan) kedua variabel tersebut berpengaruh secara signifikan terhadap pengembangan sistem informasi.

2. Secara parsial, variabel kompleksitas sistem dan partisipasi eksekutif mempunyai pengaruh yang signifikan terhadap pengembangan sistem informasi.

3. Hasil koefisien determinasi dari penelitian ini menunjukkan bahwa kedua variabel bebas tersebut yaitu partisipasi eksekutif dan kompleksitas sistem mampu menjelaskan variasi dari variabel 
pengembangan sistem informasi sebesar $18 \%$, dimana pengaruh tersebut termasuk dalam kategori sangat rendah, sedangkan $82 \%$ termasuk dalam kategori sangat kuat dipengaruhi oleh faktor lain. Faktor lain yang mempengaruhi pengembangan sistem informasi selain kedua variabel tersebut, antara lain komunikasi pemakai pengembang dan pengaruh pemakai.

\section{DAFTAR PUSTAKA}

Arikunto, Suharsimi. 2006. Prosedur Penelitian Suatu Pendekatan Praktik. Edisi Revisi VI. Jakarta: Rineka Cipta.

Baridwan, Zaki. 2000. Sistem Informasi Akuntansi. Edisi ke 2. BPFE-Yogyakarta.

Bodnar, George H. dan William S. Hopwood. 2001. Sistem Informasi Akuntansi. Jakarta: Salemba Empat. Djarwanto, Pangestu Subagyo. Statistika Induktif. Edisi 5. Yogyakarta: BPFE-Yogyakarta.

Ervianto, I. Wulfram. 2005. Manajemen Proyek Konstruksi. Edisi Revisi. Yogyakarta: Penerbit ANDI.

Ghozali, Imam. 2006. Aplikasi Analisis Multivariate dengan Program SPSS. Badan Penerbit Universitas Diponogoro.

Husein, Muhammad Fakhri dan Amin Wibowo. 2002. Sistem Informasi Manajemen. UPP AMP YKPN.

Jogiyanto, H.M. 2000. Sistem Informasi Akuntansi Berbasis Komputer. Edisi 2. BPFE-Yogyakarta.

Kuncoro, Mudrajad. 2003. Metode riset untuk Bisnis dan Ekonomi. Jakarta: Erlangga.

Lau, Efreda Aplonia. 2003. Pengaruh Partisipasi Pemakai Terhadap Kepuasan Pemakai dalam Pengembangan Sistem Informasi dengan Lima Variabel Moderating. Simposium Nasional Akuntansi VI, hal. 866-882.

Laudon, Kenneth C. dan P. Laudon. 2004. Sistem Informasi Manajemen. Edisi Delapan. Penerbit ANDI.

Limantara, Fenny dan Devie. 2003. Kualitas Jasa Sistem Informasi dan Kepuasan Para Pengguna Sistem Informasi. Simposium Nasional Akuntansi VI. Hal. 895-907.

Mayanti, Ridha. 2006. Pengaruh Partisipasi Pemakai Terhadap Kepuasan Pemakai dalam Pengembangan Sistem Informasi Pada Hotel Berbintang di Denpasar. Denpasar: Universitas Udayana.

McLeod, Raymond Jr. 2001. Sistem Informasi Manajemen. Jilid 1. Edisi ke 7. Jakarta: PT. Prenhallindo.

Mulyadi. 2001. Sistem Akuntansi. Edisi ke 3. Jakarta: Salemba Empat.

Nasir, Moh. 1999. Metodologi Penelitian. Jakarta: Ghalia Indonesia.

Siagian, S.P. 1986. Eksekutif yang Efektif. Jakarta: PT. Gunung Agung

Sugiyono. 2002. Metode Penelitian Bisnis. Bandung: CV. AlfaBeta.

Susilo, Sri dkk. 2002. Bank dan Lembaga Keuangan. Jakarta: Salemba Empat.

Umar, Husein. 2003. Metode Riset Akuntansi Terapan. Jakarta: Penerbit Erlangga.

Wirawan, Nata. 2002. Cara Mudah Memahami Statistik 2 (Satitisik Infrensia). Edisi ke 2. Denpasar: Keraras Emas.

http://edhow05.multiply.com/journal/item/3/SISTEM USER N DEVELOPER. Diakses pada tanggal

11 agustus 2010. 